\title{
HIFDZ AL-QURAN: PROGRAM UNGGULAN FULL DAY SCHOOL DALAM MEMBENTUK KARAKTER QURANI SISWA SD
}

\author{
Ani Nur Aeni* \\ Universitas Pendidikan Indonesia \\ *Email: aninuraeni@upi.edu
}

\begin{abstract}
ABSTRAK
Full day school merupakan sekolah yang memberlakukan jam sekolah secara sehari penuh..Ekstra jam pelajaran tersebut digunakan untuk pembentukan karakter siswa. Maka untuk mengelola ekstra waktu pada full day school ini dapat diterapkan Hifd Al-Quran sebagai program unggulan sebagai upaya membentuk karakter qurani siswa SD. Secara sederhana Hifdz Al-Quran diartikan dengan menghafal Al-Quran. Program hifdz Al-Quran ini dipilih mengingat Al-Quran memiliki beberapa keistimewaan terkait kedudukannya sebagai mukjizat, dan mengingat keterangan hadits mengenai keutamaan hifdz Al-Quran. Hifdz Al-Quran sangat cocok diterapkan pada siswa SD, karena daya ingat (memori) anak usia SD lebih kuat dibandingkan dengan daya memori ingat orang dewasa/tua. Untuk menghafal Al-Quran perlu memperhatikan adab-adabnya, dan adab-adab inilah yang menjadi atsar (pengaruh) terhadap karakter siswa. Hifdz Al-Quran dapat membentuk pribadi siswa menjadi pribadi yang berkarakter qurani. Berdasarkan kurikulum hifdz Al-Quran yang telah penulis rancang maka siswa di SD full day dapat menyelesaikan hafalan sebanyak 10 juz selama 6 tahun.
\end{abstract}

Kata Kunci: Full Day School, Hifdz Al-Quran, Karakter Qurani. 


\section{PENDAHULUAN}

Full day school merupakan sekolah yang memberlakukan jam sekolah secara sehari penuh. Biasanya di beberapa sekolah yang telah melaksanakan program full day school ini pelaksanaan sekolah mulai dari jam 07.00 sampai dengan pukul 15.30 atau pukul 16.00. Ada banyak sekolah yang telah melaksankan program full day school, khususnya sekolah untuk jenjang SD. Sebelum Menteri Pendidikan dan Kebudayaan (Mendikbud) Bapak Muhadjir Effendy menggulirkan wacana tentang full day school ini, kebanyakan sekolah yang menyelenggarakan full day school adalah sekolah-seolah swasta yang berada di bawah yayasan, namun setelah program ini digulirkan Mendikbud mengatakan bahwa pihak pemeritah telah mempersiapkan sekitar 500 sekolah sebagai percontohan dalam menerapkan full day school. Jumlah 500 sekolah ini berasal dari jenjang SD, SLTP, dan SLTA (kompas.com, 2016).

Mengenai program full day school ini terjadi pro dan kontra, ada pihak yang setuju dengan akan diberlakukannya dan ada juga pihak yang dengan jelas melakukan penolakannya bahkan melalui petisi yang ditandatangani oleh puluhan ribu masyarakat (kompas.com, 2016). Mengenai hal ini, penulis berada pada pihak yang setuju dengan akan diberlakukannya full day school, dengan catatan bahwa pelaksanaan full day school itu ditujukan bukan untuk pendalaman materi pelajaran yang membebani siswa, tetapi ekstra jam pelajaran tersebut digunakan untuk pembentukan karakter siswa yang ditujukan bagi kemampuan ranah afektif dan membentuk siswa yang terampil dalam pemenuhan ranah psikomotor. Jika tujuan utama dari full day school itu adalah untuk pembentukan karakter siswa, tidak ada alasan penulis untuk menolaknya, tetapi yang dikhawatirkan adalah pelaksanaan program full day school ini melenceng dari tujuan awalnya, yaitu pendidikan karakter.
Kekhawatiran ini muncul, karena pelaksanaan secara teknis full day school belum dilontarkan oleh pemeritah. Melalui makalah ini penulis mencoba menggulirkan gagasan tentang Hifd AlQuran sebagai program unggulan dalam full day school sebagai upaya membentuk karakter qurani siswa SD. Jika melihat gagasan tersebut, maka sangat jelas bahwa gagasan tersebut diperuntukkan bagi sekolah sekolah Islam atau sekolahsekolah umum yang ingin mengadopsi ajaran Islam yang dilaksanakan untuk jenjang Sekolah Dasar.

\section{HIFDZ AL-QURAN}

Hifdz Al-Quran berasal dari dua kata yaitu hifdz dan Al-Quran. Kedua-duanya berasal dari bahasa Arab. Kata Hifdz berasal dari kata hafidza-yahfadzu-hifdzan, yang artinya menjaga (jangan sampai rusak), memelihara. melindungi. Jika kata $h i f d z$ disambungkan dengan kata al-dars artinya menghafal (Al-Munawwir, 1997, hlm. 279 dan Bisri, 1999, hlm. 123). Dengan demikian jika kata hifdz disambungkan dengan kata Al-Quran mengandung makna menghafal Al-Quran, maksudnya adalah menjaga, memelihara dan melindungi Al-Quran jangan sampai rusak dengan cara menghafalnya.

Adapun kata Al-Quran berasal dari kata Qara-a - yaqra-u- qirā-atan wa Qurānan artinya membaca (Al-Munawwir, 1997, hlm. 1101 dan Bisri, 1999, hlm. 589). Ash-Shabuni $(1390 \quad \mathrm{H})$ mendefinisikan Al-Quran sebagai berikut:

Al-Quran adalah firman Allah yang tiada tandingannya, diturunkan kepada Nabi Muhammad penutup para nabi dan rasul, dengan perantaraan Malaikat Jibril dan ditulis pada mushaf-mushaf yang kemudian disampaikan kepada kita secara mutawatir, serta membaca dan mempelajarinya merupakan ibadah, yang dimulai dengan surat Al-Fatihah dan ditutup dengan surat An-Nas. 
Kata Al-Quran apabila ditinjau dari segi pengertian kalimat (word), paling tidak terdapat lima pengertian, sebagaimana yang dicantumkan dalam Ashiddieqy (1990) yaitu:

a. Pendapat Asy-Syafi'i: lafadz AlQuran yang dita'rifkan dengan "Al", tidak berhamzah (tidak berbunyi $A n$ ) an bukan diambil dari sesuatu kalimat lain, tidak diambil dari qara'tu sama dengan aku telah baca. Kalimat ini nama resmi bagi kalamullah yang diturunkan kepada Muhammad. Menurut pendapat ini Al-Quran harus dibaca dengan tidak membunyikan "a".

b. Pendapat yang diambil dari AlAsy'ary dan beberapa golongan lain, yaitu lafadz Qur-an diambil dari lafadz qarana yang berarti menggabungkan sesuatu dengan sesuatu yang lain. Kemudian lafadz Al-Quran itu dijadikan nama kalamullah yang diturunkan kepada NabiNya. Dinamai wahyu Allah ini dengan Al-Quran, mengingat bahwa surat-suratnya, ayat-ayatnya dan huruf-hurufnya beriringan yang satu digabung dengan yang lain.

c. Pendapat Al-Farra': lafadz Al-Quran diambil dari qara-'in (karinahkarinah) mengingat bahwa ayat-ayat Al-Quran itu satu sama yang lain saling membenarkan. Dan kemudian dijadikan nama resmi bagi kalam yang diturunkan tersebut.

d. Pendapat Az-Zajjaj: Al-Quran itu sewazan dengan fu'lan, yakni harus dibaca dengan bunyi Qur-an (dengan berhamzah) diambil dari kata qar-I yang berarti mengumpulkan. Dan dinamai kalamullah dengan Qur-an karena dia mengumpulkan beberapa surat, atau mengumpulkan saripati kitab-kitab yang telah lalu.

e. Pendapat Al-lihyany dan segolongan ulama, bahwa lafaz Al-Quran itu bermakna yang dibaca (mashdar dari isim maf'ul). Karena Al-Quran itu dibaca, maka kalamullah itu dinamai dengan Al-Quran, dan inilah pendapat yang terkenal.

Secara sederhana Hifdz Al-Quran diartikan dengan menghafal Al-Quran, yaitu menghafal ayat-ayat yang terdapat dalam mushaf Al-Quran berdasarkan urutan nomor surat yang ada pada mushaf bukan didasarkan pada urutan turunnya ayat Al-Quran sebagai salah satu upaya untuk menjaga kemurnian Al-Quran, sehingga Al-Quran tetap terjaga keasliannya.

Kata "menghafal" menurut KBBI (2005, hlm. 381) berarti berusaha meresapkan ke dalam pikiran agar selalu ingat. Sedangkan kata hafal berarti dapat mengucapkan di luar kepala (tanpa melihat buku atau catatan yang lain). Menghafal Al-Quran berarti memindahkan Al-Quran dari tulisan ke dalam dada (Al Hafidz, 1995, hlm 2), hal ini menjadi ciri khas seorang yang diberi ilmu juga sebagai tolak ukur keimanan dalam hati seseorang (Q.S. Al-'Ankabut [29]: 49).

\section{MENGAPA HIFDZ AL-QURAN?}

Gagasan tentang Hifdz Al-Quran ini muncul mengingat pada dua alasan keistimewaan, yaitu keistimewaan pada Al-Qurannya dan keistimewaan pada $h i f d z$ Al-Qurannya.

Alasan pertama: keistimewaan AlQuran, karena Al-Quran sebagai pedoman dan sumber hukum umat Islam yang senantiasa dijaga kemurniaannya oleh Allah SWT (Q.S. Al-Hijr [15]: 9). Salah satu cara Allah SWT menjaga kemurniaan Al-Quran adalah sampai saat ini tidak ada seorangpun atau pihak manapun yang berhasil memalsukan Al-Quran, sekalipun upaya untuk memalsukannya telah banyak dilakukan tetapi selalu gagal, dan digagalkan oleh Allah dengan caranya Allah sendiri. Ini sebagai bukti janji Allah pada Q.S. Al-Hijr tersebut selama lebih dari 14 abad semenjak diturunkannya AlQuran, ia tetap asli sebagaimana saat diturunkan. Juga sebagaimana 
disampaikan oleh Rasulullah SAW, kemudian diterima oleh para sahabat dan selanjutnya oleh generasi setelah mereka dari satu generasi ke generasi yang lainnya, menurut Al-Qaradhawi (1999, hlm. 43) dengan cara dipelihara di dalam hati, dibaca dengan lidah, tertulis dengan mushaf, dan dihafal oleh puluhan ribu kaum muslimin, hingga anak-anak bahkan orang-orang non Arab yang tidak mengerti bahasa Arab.

Selain itu bukti bahwa Al-Quran itu dijaga kemurniannya adalah Al-Quran itu mudah untuk dihafal (Q.S. Al-Qomar [54]: 17). Mengapa Al-Quran mudah dihafal? Karena Al-Quran itu adalah kalamullah yang merupakan mukjizat, bukan kalam manusia yang merupakan buku teks biasa. Susunan kalimat yang ada dalam Al-Quran memudahkan untuk dihafal, karena memiliki beberapa keistimewaan, diantaranya kalimat kalimat/ayat yang ada dalam Al-Quran banyak yang diulangulang, seperti dalam:

1. Q.S. Ar-rahmān [55] kalimat Fabiayyi 'ālāi robbikumā tukadzibān (maka nikmat yang mana lagi yang kalian dustakan?) diulang sebanyak 31 kali dalam 31 ayat, yaitu ayat ke-13, 16, 18, 21, $23,25,28,30,32,34,36,38,40$, $42,45,47,49,51,53,55,57,59$, $61,63,65,67,69,71,73,75$, dan 77.

2. Q.S. Al-Qomar [54] kalimat $W a$ laqad yassarnal qur-āna li dzikri, fahal min muddakir (Dan sesungguhnya telah kami mudahkan Al-Qur an untuk dipelajari maka adakah yang mau mempelajarinya) diulang sebanyak empat kali dalam empat ayat yaitu ayat ke- 17, 22, 32 dan 40.

3. Q.S. Al-Mursalāt [77] kalimat Wailuy yauma-idzin lil mukadzdzib̌n (Celakalah pada hari itu bagi mereka yang mendustakan) diulang sebanyak sepuluh kali pada sepuluh ayat, yaitu pada ayat ke $-15,19,24,28,34,37,40,45$, 47, 49.

4. Q.S. Al-Kāfirūn (109) kalimat wa lā antum ābidūna mā a'bud (dan kalian bukan penyembah apa yang aku sembah) diulang sebanyak dua kali dalam dua ayat yaitu pada ayat ke-3 dan ayat ke-4

5. Q.S. Al-Insyirāh (94) kalimat inna ma'al 'usri yusrā (sesungguhnya bersama kesulitan ada kemudahan) diulang sebanyak dua kali pada dua ayat, yaitu pada ayat ke-5 dan ayat ke-6

Alasan kedua: keistimewaan hifdz Al-Quran. Bagi para penghafal Al-Quran akan mendapatkan keistimewaan berupa:

1. Kedudukannya di dunia dimuliakan, berdasaran kepada H.R. Tirmidzi. Rasulullah bersabda: "Pelajarilah AlQuran dan bacalah, sesungguhnya perumpamaan orang yang mempelajari Al-Quran dan membacanya adalah seperti tempat air penuh dengan minyak wangi misik, harumnya menyebar kemanamana. Dan barang siapa mempelajarinya kemudian dia tertidur dan di dalam hatinya terdapat hafalan Al-Quran adalah seperti tempat air yang tertutup dan berisi minyak wangi misik.

2. Mendapatkan kehormatan di akhirat kelak, berdasarkan kepada H.R. Tirmidzi. Dari Abi Hurairoh ra, Rasulullah bersabda: "Penghafal AlQuran akan datang pada hari kiamat, kemudian Al-Quran akan berkata, "wahai Tuhanku, pakaikanlah pakaian untuknya", kemudian orang itu dipakaikan mahkota karamah (kehormatan). Al-Quran kembali meminta, "Wahai Tuhanku tambahkanlah" lalu orang itu ditambahkan jubbah karamah. Kemudian Al-Quran memohon lagi "Wahai Tuhanku ridhailah" Allah SWT pun meridhainya. Dan 
diperintahkan kepada orang itu, "Bacalah dan teruslah naiki (derajatderajat surga). Allah menambahkan dari setiap ayat yang dibacanya tambahan nikmat dan kebaikan".

3. Orang tuanya mendapatkan cahaya kehormatan, berdasarkan kepada H.R. Al-Hakim. Buraidah berkata, telah bersabda Rasulullah SAW: "Barangsiapa yang membaca AlQuran, mempelajarinya dan mengamalkannya maka dipakaikan mahkota dari cahaya pada hari kiamat. Cahanya seperti cahaya matahari dan kedua orang tuanya dipakaian dua jubbah (kemuliaan) yang tidak pernah didapatkan di dunia. Keduanya bertanya: "Mengapa kami dipakaikan jubbah ini?" karena kalian berdua memerintahkan anak kalian untuk mempelajari Al-Quran.

\section{HIFDZ AL-QURAN UNTUK SISWA SD}

Untuk menjawab pertanyaan tersebut didasarkan pada tiga alasan, yaitu 1) alasan tentang daya ingat (memori) anak, 2) didasarkan pada penanamkan karakter anak, 3) didasarkan pada sejarah (Historis).

Siswa SD ada pada kisaran usia 612 tahun, pada usia ini jika dilihat dari kekuatan hafalan, jelas lebih kuat dibandingkan dengan usia masa dewasa/tua. Dalam peribahasa Arab dikatakan, "Al-Ilmu fish shighāri kanaqsi 'alal hajar" (menuntut ilmu di waktu kecil bagaikan melukis di atas batu). Hal ini mengandung pengertian bahwa belajar pada waktu kecil sangat membekas dan sangat sulit untuk hilang atau lupa. Pada masa golden age memori anak berada pada masa perkembangan yang pesat. Anak lebih mudah mengingat dari apa yang mereka lihat dan dari apa yang mereka dengar.

Memori ingtan anak lebih kuat dari pada memori orang dewasa. Sebagian besar ingatan seseorang itu ada pada memorinya ketika masa kecil. Seorang akan lebih banyak mengingat masa kecilnya dari masa dewasanya karena memorinya telah banyak dipenuhi oleh memori pada masa kecilnya, jika dianalogikan daya ingat (memori) itu seperti flashdisk atau tempat menyimpan data. Ketika flashdisk itu masih kosong atau daya tampungya masih banyak (diibaratkan usia dini) maka akan sangat mudah menyimpan data, dan jika flashdisk itu sudah mulai banyak menyimpan data bahkan sudah penuh (diibaratkan usia dewasa/tua) maka akan terjadi ploblem ketika akan menyimpan data.

Hifdz Al-Quran pada siswa SD didasarkan pada penanaman karakter. Penanaman karakter harus dimulai sejak dini, karena usia dini diibaratkan seperti pondasi rumah, yang akan membangun bangunan yang megah. Supaya bangunan itu kokoh tidak hanya sekedar indah desainnya, tetapi kuat jika ditimpa bencana longsor, angin topan, banjir, gempa dll adalah dikarenakan pondasinya yang kuat. Maka pendidikan karakater pada usia dini porsinya sangat besar bahkan lebih besar bila dibandingkan pada usia SMP dan SMA. Untuk tingkatan Sekolah Dasar (SD) pendidikan karakter ditentukan sebesar 70 persen, SLTP sebesar 60 persen, dan SLTA sebesar 30 persen yang difokuskan pada pendidikan karakter untuk memasuki dunia kerja.

Penanaman karakter melalui hifdz Al-Quran pada usia SD sebagai upaya penanaman kebiasaan-kebiasaan baik yang akan mengakar pada diri siswa, dan akan berlanjut pada usia berikutnya.

Hifdz Al-Quran pada siswa SD juga didasarkan pada sejarah. Secara historis, para ulama, ilmuwan dan intelektual muslim telah mendapatkan pendidikan Islam semenjak kecil, dan mereka telah hafal Al-Quran sejak usia belia pula, misalnya:

1. Imam Syafi'i (hidup pada tahun 150204 H) peletak Madzhab Asy- 
Syafi'iyyah, beliau berhasil menghafal Al-Quran 30 juz di usia tujuh tahun.

2. Imam Suyuthi, penyusun beberapa kitab, diataranya tafsir jalalain dan tafsir Al-Durrul mantsur. pada usia delapan tahun beliau telah hafal 30 juz Al-Quran.

3. Imam Ath-Thabari (hidup pada tahun 224-310 H). Beliau hafal AlQuran pada usia tujuh tahun. Beliau adalah ahli tafsir.

4. Ibnu Sina (hidup pada tahun 370-428 $\mathrm{H})$. Beliau telah hafal Al-Quran saat usia lima tahun, beliau ahli kedokteran, peletak dasar ilmu kedokteran.

5. Ibnu Khaldun (732-808 H). Beliau hafal Al-Quran saat usia tujuh tahun. Beliau adalah ahli sosiologi dan ahli konstruksi.

\section{MENGAPA HIFDZ AL-QURAN PADA FULL DAY SCHOOL?}

Hifdz Al-Quran sebagai program unggulan dapat dilaksanakan di full day school karena full day school memiliki ekstra waktu dibandingkan dengan sekolah regular. Kelebihan waktu pada full day school harus dikelola dengan kegiatan yang membuat siswa senang, betah di sekolah, bermanfaat dan bermakna, bukan sebaliknya membuat siswa jenuh, dan terbebani sehingga menjadi stress.

Program Hifdz Al-Quran sangat memungkinkan diterapkan di sekolah yang full day karena sekolah merupakan lembaga pendidikan formal, artinya didukung secara sistem, terprogram, dan terdapat kurikulumnya, target keberhasilannya jelas dan mudah untuk dievaluasi. Kegiatan hifdz (menghapal) AlQuran memerlukan kekonsistenan (dawam/istiqamah), waktu yang luang, ada murabbi, serta harus dilaksanakan berdasarkan program yang jelas. Syaratsyarat ini ada pada full day school. Sedangkan syarat bahwa semua siswa harus sudah bisa membaca Al-Quran hanya menjadi syarat bagi siswa kelas tinggi. Untuk siswa kelas rendah walaupun mereka belum bisa dan belum lancar membaca huruf Al-Quran, kegiatan hifdz Al-Quran tetap dapat dilaksanakan. Karena menghafal itu dapat dilakukan dengan cara mendengarkan langsung dari orang yang membaca Al-Quran atau melalui media atau dengan cara membaca langsung mushaf Al-Quran.

Pada full day school keberadaan siswa di lingkungan sekolah lebih lama dibandingkan dengan siswa di sekolah regular. Perbedaan waktunya bisa berbeda antara 3-4 jam setiap harinya, jika jam belajar sekolah regular antara pukul 07.0012.00 (kelas tinggi), maka jam belajar full day school antara 07.00-15.30/16..00 (kelas tinggi). Maka melebihkan waktu selama 3-4 jam perhari artinya harus melebihkan kemampuan siswa yang ada di sekolah regular dengan full day school, dan inilah yang disebut sebagai keunggulannya melalui program unggulan hifdz Al-Quran.

pengelolaa waktu yang 3-4 jam/hari itu dapat dipergunakan dengan program menghafal AL-Quran1/2 sampai 1 halaman Al-Quran perhari. Hari sekolah untuk full day school biasanya sampai hari Jum'at, sama dengan 5 hari sekolah. Jika dihitung 1 juz itu terdapat 16 halaman, dan targetnya 1 hari setengah halaman maka 16 halaman X $2=32$ halaman: 5 hari $=6$ minggu 2 hari, artinya 1 juz dapat diselesaikan dalam 32 hari atau 6 minggu 2 hari, atau 1,5 bulan. Dapat dihitung kasar 1 juz dihafal dalam target waktu 2 bulan (jika konsisten, dan terprogram), maka untuk kelas tinggi dalam satu semester dapat menempuh hafalan 2 juz (dihitung hari efektif), sehingga 1 tahun dapat menghasilkan hafalan 4 juz - 1 juz untuk muraja'ah, sehingga 1 tahun menghasilkan hafalan 3 juz. Perhitungan ini berbeda dengan peruntukan siswa di kelas rendah, karena jam belajar full day school kelas rendah biasanya sedikit lebih singkat dari kelas tinggi, mengingat 
kemampuan untuk menghafal secara mandiri kelas tinggi lebih mandiri dari kelas rendah. Untuk itu target untuk kelas rendah dapat dikurangi dari kelas tinggi.

Dari perhitungan target hafalan tersebut, maka dapat disimpulkan bahwa hifdz Al-Quran dapat dijadikan program unggulan untuk full day school.

\section{KURIKULUM HIFDZ AL-QURAN PADA FULL DAY SCHOOL JENJANG SD}

Menyambung

pembahasan sebelumya tentang perhitungan target hafalan, penulis mencoba membuat gagasan kurikulum Hifdz Al-Quran untuk siswa SD.

Tabel 1

Rancangan Kurikulum Hifdz, Al-Quran untuk Siswa SD pad Full Day School

\begin{tabular}{|c|c|c|c|}
\hline \multirow{2}{*}{$\begin{array}{c}\text { Kel } \\
\text { as }\end{array}$} & \multicolumn{3}{|c|}{ Surat } \\
\hline & Nama & No & Arti \\
\hline \multirow[t]{20}{*}{ I } & At-Tĭn & 95 & Buah Tin \\
\hline & Al'Alaq & 96 & $\begin{array}{l}\text { Segumpal } \\
\text { Darah }\end{array}$ \\
\hline & Al- Qadr & 97 & Kemuliaan \\
\hline & Al- Bayyinah & 98 & $\begin{array}{c}\text { Bukti yang } \\
\text { Nyata }\end{array}$ \\
\hline & Az- Zalzalah & 99 & Keguncangan \\
\hline & Al-'ādiyāt & 100 & $\begin{array}{c}\text { Kuda Perang } \\
\text { yang Berlari } \\
\text { Kencang }\end{array}$ \\
\hline & Al- Qāri’ah & 01 & Hari Kiamat \\
\hline & At-Takātsur & 102 & $\begin{array}{l}\text { Bermegah- } \\
\text { Megahan }\end{array}$ \\
\hline & $\mathrm{Al}$ 'Asr & 103 & Masa \\
\hline & Al- Humazah & 104 & Pengumpat \\
\hline & Al- Fîl & 105 & Gajah \\
\hline & Al- Quraisy & 106 & Suku Quraysy \\
\hline & Al- Mā'ūn & 107 & $\begin{array}{c}\text { Barang- } \\
\text { Barang Yang } \\
\text { Berguna }\end{array}$ \\
\hline & Al- Kautsar & 108 & $\begin{array}{c}\text { Nikmat Yang } \\
\text { Banyak }\end{array}$ \\
\hline & Al Kāfirūn & 109 & $\begin{array}{c}\text { Orang-orang } \\
\text { Kafir }\end{array}$ \\
\hline & An- Nasr & 110 & Pertolongan \\
\hline & Al- Lahab & 111 & Gejolak Api \\
\hline & Al- Ikhlās & 112 & $\begin{array}{c}\text { Memurnikan } \\
\text { Keesaan Allah }\end{array}$ \\
\hline & Al- Falāq & 113 & Waktu Subuh \\
\hline & An- Nās & 114 & Manusia \\
\hline II & Ath-Thārīq & 86 & $\begin{array}{l}\text { Yang Datang } \\
\text { di Malam Hari }\end{array}$ \\
\hline
\end{tabular}

\begin{tabular}{|c|c|c|c|}
\hline & Al-A'lā & 87 & $\begin{array}{c}\text { Yang Paling } \\
\text { Tinggi }\end{array}$ \\
\hline & Al-Ghāsyiyah & 88 & $\begin{array}{c}\text { Hari } \\
\text { Pembalasan }\end{array}$ \\
\hline & Al-Fajr & & Fajar \\
\hline & Al-Balad & 90 & Negeri \\
\hline & Asy-Syams & 91 & Matahari \\
\hline & Al-Lail & 92 & Malam \\
\hline & Ad-Dhuhā & 93 & Waktu Dhuha \\
\hline & Al- Insyirah & 94 & Kelapangan \\
\hline \multirow[t]{8}{*}{ III } & An-Naba' & 78 & Berita Besar \\
\hline & An-Nāzi' āt & 79 & $\begin{array}{c}\text { Malaikat- } \\
\text { malaikat yang } \\
\text { Mencabut }\end{array}$ \\
\hline & 'Abasa & 80 & $\begin{array}{l}\text { Ia Bermuka } \\
\text { Masam }\end{array}$ \\
\hline & At-Takwĭr & 81 & Menggulung \\
\hline & Al-Infithār & 82 & Terbelah \\
\hline & Al-Muthaffifin & 83 & Kecurangan \\
\hline & Al-Insyiqaq & 84 & Terbelah \\
\hline & Al-Burūj & 85 & $\begin{array}{c}\text { Gugusan } \\
\text { Bintang }\end{array}$ \\
\hline \multirow[t]{23}{*}{ IV } & Adz-Dāriyāt & 51 & $\begin{array}{c}\text { Angin Yang } \\
\text { Menerbangkan }\end{array}$ \\
\hline & Ath -Thūr & 52 & bukit \\
\hline & An-Najm & 53 & Bintang \\
\hline & Al- Qomar & 54 & Bulan \\
\hline & Ar- Rahmān & 55 & $\begin{array}{c}\text { Yang Maha } \\
\text { Pemurah }\end{array}$ \\
\hline & Al- Wāqi'ah & 56 & Hari Kiamat \\
\hline & Al- Hadĭd & 57 & Besi \\
\hline & Al-Mujādilah & 58 & $\begin{array}{c}\text { Wanita yang } \\
\text { Mengajukan } \\
\text { Gugatan }\end{array}$ \\
\hline & Al- Hasyr & 59 & Pengusiran \\
\hline & Al-Mumtahanah & 60 & $\begin{array}{l}\text { Perempuan } \\
\text { yang Diuji }\end{array}$ \\
\hline & Ash- Shaff & 61 & Barisan \\
\hline & Al- Jumu'ah & 62 & Hari Jum'at \\
\hline & Al- Munāfiqūn & 63 & $\begin{array}{c}\text { Orang-Orang } \\
\text { Munafiq }\end{array}$ \\
\hline & At- Taqhābūn & 64 & $\begin{array}{c}\text { Hari } \\
\text { Ditampakkan } \\
\text { Segala } \\
\text { Kesalahan }\end{array}$ \\
\hline & Ath- Thalaq & 65 & Talak \\
\hline & At- Tahrǐm & 66 & $\begin{array}{c}\text { Mengharamka } \\
n\end{array}$ \\
\hline & Al- Mulk & 67 & Kerajaan \\
\hline & Al- Qalam & 68 & Kalam \\
\hline & Al- Hāqqah & 69 & Hari Kiamat \\
\hline & Al- Ma’ārij & 70 & $\begin{array}{c}\text { Tempat- } \\
\text { tempat Naik }\end{array}$ \\
\hline & Nūh & 71 & Nuh \\
\hline & Al -Jinn & 72 & Jin \\
\hline & Al- Muzzammil & 73 & $\begin{array}{l}\text { Orang yang } \\
\text { Berselimut }\end{array}$ \\
\hline
\end{tabular}




\begin{tabular}{|c|c|c|c|}
\hline & Al- Muddatstsir & 74 & $\begin{array}{l}\text { Orang Yang } \\
\text { Berkemul }\end{array}$ \\
\hline & Al-Qiyāmah & 75 & Hari Kiamat \\
\hline & Al- Insān & 76 & Manusia \\
\hline & Al- Mursalāt & 77 & $\begin{array}{c}\text { Malaikat- } \\
\text { malaikat yang } \\
\text { Diutus }\end{array}$ \\
\hline \multirow[t]{12}{*}{$\mathrm{V}$} & Az-Zumar & 39 & $\begin{array}{c}\text { Rombongan- } \\
\text { rombongan }\end{array}$ \\
\hline & Gāfir & 40 & $\begin{array}{c}\text { Yang } \\
\text { mengampuni }\end{array}$ \\
\hline & Fushshilat & 41 & $\begin{array}{c}\text { Yang } \\
\text { dijelaskan }\end{array}$ \\
\hline & Asy-Syurā & 42 & Musyawarah \\
\hline & Az-Zukhruf & 43 & Perhiasan \\
\hline & Ad-Dukhān & 44 & Kabut \\
\hline & Al-Jātsiyah & 45 & Yang Berlutut \\
\hline & Al-Ahqāf & 46 & $\begin{array}{l}\text { Bukit-Bukit } \\
\text { Pasir }\end{array}$ \\
\hline & Muhammad & 47 & $\begin{array}{c}\text { Nabi } \\
\text { Muhammad } \\
\text { SAW }\end{array}$ \\
\hline & Al-Fath & 48 & Kemenangan \\
\hline & Al-Hujurāt & 49 & Kamar-Kamar \\
\hline & Qaf & 50 & Qaf \\
\hline \multirow[t]{10}{*}{ VI } & Al- 'Ankabūt & 29 & Laba-laba \\
\hline & Ar-Rūm & 30 & $\begin{array}{c}\text { Kaum } \\
\text { Romawi }\end{array}$ \\
\hline & Luqmān & 31 & Luqman \\
\hline & As-Sajdah & 32 & Sujud \\
\hline & Al-Ahzāb & 33 & $\begin{array}{l}\text { Golongan } \\
\text { yang } \\
\text { Bersekutu }\end{array}$ \\
\hline & Saba' & 34 & Kaum Saba' \\
\hline & Fāthir & 35 & Pencipta \\
\hline & Yā Sĭn & 36 & Yā Sĭn \\
\hline & Ash-Shaffāt & 37 & $\begin{array}{c}\text { Yang Bersaf- } \\
\text { saf }\end{array}$ \\
\hline & Sād & 38 & Sād \\
\hline
\end{tabular}

CARA HIFDZ AL-QURAN

Menghafal AL-Quran merupakan cara memindahkan AL-Quran dalam bentuk tulisan ke dalam dada, sehingga dapat dibacakan kembali tanpa melihat tulisan. Menghafal Al-Quran dapat dilakukan secara mandiri. Pada saat menghafal Al-Quran dapat mengikuti langkah-langkah yang dirumuskan oleh Amiruddin dan Imana (2010) dalam bukunya mudah dan cepat pahami AlQuran, yaitu terdapat 4 langkah, yaitu:
Langkah pertama dalam menghafal Al-Quran, ada beberapa hal yang harus diperhatikan, yaitu:

1. Berusaha mengamalkan apa yang dihafal

2. Berusaha menjauhi kemaksiatan dan perbuatan dosa

3. Berdo'a agar dimudahkan dalam menghafal al-quran

4. Memilih tempat yang sesuai

5. Memanfaatkan waktu senggang

6. Menggunakan satu jenis mushaf

7. Membaguskan bacaan (tahsin, tilawah) al-quran

8. Memahami ayat yang akan dihafal

9. Kurikulum yang jelas setiap harinya

10. Jangan menghafal melebihi batasan harian, sampai dapat hafal dengan sempurna

11. Sering mengulang ayat yang telah dihafal

12. Jangan beralih kepada surat yang lain sebelum benar-benar hafal

13. Memperhatikan ayat-ayat yang mirip

14. Senantiasa memperdengarkan hafalan

15. Bergabung dalam sebuah kelompok

Langkah kedua dari cara menghafal Al-Quran adalah memperhatikan cara menghafal, langkah-langkahnya meliputi:

1. Memperhatikan mushaf yan digunakan

2. Membaca secara jahriyyah (bersuara) dan memperhatikan kaidah-kaidah bacaan

3. Memperhatikan halaman demi halaman, ayat demi ayat secara cermat

4. Membaca tanpa irama terlebih dahulu, setelah hafal baru boleh dengan irama

5. Buatlah lembar fotocopy ayat yang dibaca lalu tempel di dinding yang memungkinkan kita nyaman untuk melihatnya

6. Membaca dan mengulangi hafalan sambil memperhatikan 
7. Saat mobil melaju baca dan ulangi hafalan

8. Apabila mobil berhenti

9. Menyiapkan kaset, MP3, VCD murottal dengarkan sampai tiga kali pengulangan

10. Membaca surat atau halaman tersebut dengan

Langkah ketiga adalah menyetorkan halaman, langkah-langkahnya meliputi:

1. Menyetorkan hafalan kepada pembimbing

Langkah keempat adalah berusaha menjaga agar hafalan tidak cepat hilang, langkahnya meliputi:

1. Membuat perencanaan waktu yang tepat

2. Berusaha menyediakan waktu khusus

3. Senantiasa melaksanakan tilawah Al-Quran

4. Mendengarkan kaset, mp3 atau ved murottal Al-Quran

5. Mendengarkan bacaan Al-Quran orang lain

6. Membaca ayat yang dihafal di dalam shalat

7. Menjadi imam shalat atau mendengarkan bacaan imam dengan seksama

8. Membiasakan membaca Al-Quran tanpa melihat mushaf

9. Mengajarkan hafalan al-quran kepada orang lain

10. Selalu membawa Al-Quran kecil dalam saku

11. Memulai dari juz-juz yang mudah untuk dihafal

12. Berusaha menghindari kemaksiatan dan perbuatan dosa.

Para penghafal Al-Quran hendaknya senantiasa menjaga hafalannya, dengan selalu melakukan muraja'ah yang berkala. Menuliskan kembali dalam bentuk tulisan ayat Al-Quran yang telah dihafal adalah sebagai upaya dalam menjaga hafalan. Melalui cara ini tiga kemampuan dapat diperoleh secara sekaligus, yaitu kemampuan menghafal, menulis dan membaca.

\section{CARA MENGAJARKAN HIFDZ $A L-Q U R A N$ KEPADA SISWA SD}

Mengajarkan hifdz AL-Quran kepada siswa SD harus disesuaian dengan karakteristik siswa SD. Siswa SD cenderung pada usia senang bermain. Mengajarkan menghafal Al-Quran pada prinsifnya dilakukan secara tikrar (mengulang-ulang). Karena berdasarkan kemampuan manusia untuk menghafal melibatkan memori di dalam otak. Memori manusia terdiri dari dua jenis, yaitu memori jangka panjang dan memori jangka pendek. Menghafal AL-Quran melibatkan kedua jenis memori tersebut, artinya ketika sudah berhasil menghafal satu ayat, maka harus terus diulang-ulang supaya hafalan tersebut tidak hilang dari memori. Menghafal Al-Quran tidak ada artinya jika tidak dilakukan secara pengulangan (muraja'aah/tikrar) karena hanya melibatkan memori jangka pendek yang bersifat segera dan belum tersimpan, berbeda jika melibatkan memori jangka panjang dengan dilakukannya pengulangan.

Adapaun mengajarkannya dapat dilakukan dengan:

1. Metode kinestetik. Metode ini dikembangkan oleh Laili Tri Lestari seorang ibu asal dari Bone Sulawesi, yang menerapkan metode ini awalnya pada anaknya sendiri, yaitu melalui metode gerak dan body language. Melalui metode ini sekaligus dapat menyeimbangkan perkembangan otak anak.

2. Metode permainan petak umpet

3. Dengan menggunakan media kartu kalimat/ayat

4. Dengan cara membacakan ayat AlQuran secara berulang-ulang lalu meminta siswa untuk mengulanginya

5. Dengan cara memperdengarkan lantunan ayat Al-Quran melalui 
media audio visual secara berulangulang dan meminta siswa untuk mengikutinya

6. Dengan cara meminta siswa untuk membaca ayat Al-Quran secara berulang-ulang (bagi yang sudah mampu membaca Al-Quran)

7. Dengan cara menempel beberapa tulisan dari ayat Al-Quran di tempattempat yag sering dijumpai atau mudah dilihat oleh anak.

Melalui kreativitas dan daya imajinasi, para pendidik dapat mengembangkan berbagai metode mengajarkan hifdz Al-Quran.

\section{BAGAIMANA HIFDZIL QURAN DAPAT MEMBENTUK KARAKTER QURANI DIRI SISWA?}

Pada prinsifnya Al-Quran itu mudah untuk dihafal, namun dalam prakteknya ada orang yang dengan cepat dan ada juga yang memerlukan waktu yang lebih lama untuk menghafalnya. Kemudahan menghafal AL-Quran dalam waktu yang singkat sangat didukung oleh faktor eksternal dan faktor internal. Faktor ektsernal berkaitan dengan faktor luar yang tidak ada kaitannya dengan kesucian diri, misalnya berkaitan dengan tempat menghafal, waktu menghafal, mushaf yang digunakan, irama/lagu yang dipakai, dll. Sedangkan faktor internal berkaitan dengan kesucian diri. Berkaitan dengan kesucian diri ini para penghafal Al-Quran 1) harus menjauhkan diri dari perbuatan yang mendatangkan dosa, baik dosa kecil maupun dosa besar, 2) hanya memakan makanan yang halal (dzat, cara memperoleh, dan cara pengolahannya), 3) selalu dalam keadaan suci.

Berkaitan dengan kesucian diri ini Syu'aib (2012, hlm. 55) menyebutnya sebagai adab bagi para penghafal AlQuran, diantara adab-adab menghafal AlQuran ialah

1. mesti berada dalam keadaan paling sempurna dan perilaku paling mulia;
2. menjauhkan diri dari segala sesuatu yang dilarang Al-Quran;

3. hendaklah terpelihara dari pekerjaan yang rendah;

4. berjiwa mulia;

5. lebih tinggi derajatnya dari pengusaha yang sombong dan pecinta dunia yang jahat;

6. merendahkan diri kepada orangorang shaleh dan ahli kebaikan, serta kaum miskin;

7. khusyu memiliki ketenangan dan wibawa;

8. menghindarkan diri dari perbuatan menjadikan Al-Quran sebagai sumber penghasilan atau pekerjaan dalam hidupnya;

9. penghafal Al-Quran lebih banyak membaca Al-Quran pada waktu malam dan dalam shalat malam.

Sedangkan Al-Qaradhawi (1999, hlm. 200-208) secara garis besar menyebutkan adab penghafal Al-Quran adalah:

1. Selalu bersama Al-Quran

Penghafal Al-Quran harus selalu bersama Al-Quran, sehingga Al-Quran tidak hilang dari ingatannya. Caranya dengan terus membacanya melalui hafalan dengan membaca dari mushaf, atau mendengarkan pembacaannya dari radio atau kaset rekaman. Penghafal Al-Quran harus menjadikan Al-Quran sebagai temannya dalam kesendiriannya, serta penghiburnya dalam kegelisahannya sehingga tidak berkurang dari hafalannya.

2. Berakhlak dengan akhlak Al-Quran

Penghafal Al-Quran hendaklah berakhlak dengan akhlak Al-Quran sebagaimana Rasulullah "Akhlak nabi adalah Al-Quran". Penghafal Al-Quran harus menjadi kaca tempat orang dapat melihat akidah Al-Quran, nilai-nilainya, etika-etikanya, dan akhlaknya agar ia membaca membaca Al-Quran dan ayatayat itu sesuai dengan perilakunya. Bukan sebaliknya, ia membaca Al-Quran namun Al-Quran melaknatnya. 
3. Ikhlas dalam Menghafal Al-Quran

Para penghafal Al-Quran harus mengikhlaskan niatnya dan mencari keridloan Allah swt bukan untuk pamer di hadapan manusia dan juga tidak untuk mencari dunia. Para penghafal Al-Quran harus bertaqwa kepada Allah SWT dan mengikhlaskan amalannya kepada-Nya, sedangkan perbuatan dan niat buruk yang pernah terjadi sebelumnya, maka harus segera melakukan taubat dan kembali kepada Allah SWT untuk kemudian memulai dengan keikhlasan dalam menuntut ilmu dan beramal.

Memperhatikan adab-adab penghafal Al-Quran tersebut beserta faktor internal pendukung kemudahan dalam menghafal Al-Quran maka sudah dapat disimpulkan bahwa adab-adab tersebut dapat membentuk para penghafal AlQuran memiliki karakter yang tak jauh dari yang dihafalnya, yaitu berkarakter qurani. Kita dapat bayangkan jika siswa SD memperhatikan dan mengimplementasikan adab-adab tersebut maka atsar dari menghafal Al-Quran itu akan terbentuk siswa SD yang berkarakter qurani, dengan ciri utama berakhlak mulia, menghindari perbuatan yang tercela dan dosa, dan selalu ikhlas dalam berbuat. Inilah karakter anak yang selalu didambakan oleh setiap orang tua dan diidam-idamkan oleh seluruh pendidik.

Melalui hifdz Al-Quran di SD terbentuk karakter siswa yang diharapkan oleh pemerintah, yaitu sebagaimana yang dikatakan oleh Effendy (Kompas.com, 2016) ada empat poin yang menjadi inti dalam pendidikan karakter itu yaitu karakter tentang keagamaan, karakter tentang personal peserta didik, karakter sosial, serta karakter nasionalisme.

\section{KESIMPULAN}

Program unggulan hifdz Al-Quran dapat diterapkan di full day school mengingat ekstra waktu yang tersedia di full day school. Hifdz Al-Quran dapat membentuk pribadi siswa menjadi pribadi yang berkarakter qurani, karena untuk menghafal Al-Quran perlu memperhatikan adab-adabnya. Dan adab-adab inilah yang menjadi atsar (pengaruh) terhadap karakter siswa. Berdasarkan kurikulum hifdz Al-Quran yang telah penulis rancang maka siswa di SD full day dapat menyelesaikan hafalan sebanyak 10 juz selama 6 tahun. Kemampuan dan kelancaran membaca Al-Quran tidak menjadi syarat utama untuk dapat menghapal Al-Quran, karena menghafal Al-Quran dapat dilakukan dengan indera pendengaran melalui media audio ataupun tanpa media (mendengarkan langsung dari orang orang yang membaca), tetapi untuk dapat hifdz Al-Quran secara mandiri maka harus mamu membaca Al-Quran.

\section{REFERENSI}

Al-Quran

Al-Hafidz, A. A. A. R.. 1995. Pedoman Dauroh Al-Quran (Buku I). Jakarta: Dzilal Press.

Al-Qaradhawi, Y. 1999. Berinteraksi Dengan Al-Quran. Terjemahan Abdul Hayyie Al-Kattani. Jakarta: Gema Insani Press.

Amirudin, A dan Imana, Y. 2010 Mudah dan Cepat Pahami Al-Quran. Bandung: Khazanah Intelektual

Ash-Shabuni, 1390 H. Al-Thibyân Fî 'Ulûmi Al-Qur ân. Jakarta: Dinamika Berkah Utama.

Ash-Shiddieqy, H. 1990. Sejarah dan Pengantar Ilmu Al-Quran/Tafsir. Jakarta: Bulan Bintang. 
Bisri, A dan Fatah, A.M. 1999. Kamus

Indonesia-Arab Arab-Indonesia Al-

Bisri. Surabaya: Pustaka Progressif.

Kompas. com (2016, 15 Agustus).

Mendikbud Muhadjir Effendy

Tanggapi Petisi Penolakan Full Day

School. Diperoleh 17 April 2017, dari

http://nasional.kompas.com/read/201 6/08/15/17290131/mendikbud.muha djir.effendy.tanggapi.petisi.penolaka n.full.day.school.

Kompas. com (2016, 26 September).

Pemerintah Tetapkan 500 Seolah Jadi Percontohan Full Day School.
Dipeoleh 17 April 2017, dari http://nasional.kompas.com/read/201 6/09/26/11010561/pemerintah.tetapk an.500.sekolah.jadi.percontohan.full. day.school.

Munawwir, A.W. 1997. Al-Munawwir: Kamus Arab-Indonesia Terlengkap. Surabaya: Pustaka Progressif.

Syu'aib. S.A. 2012. Menjiwai Al-Quran. Terjemahan Muh. Alif. Yogyakarta: Mumtaz.

Tim Penyusun. 2005. Kamus Besar Bahasa Indonesia. Jakarta: Balai Pustaka. 